\title{
Use of Noninvasive Ventilation and High-Flow Nasal Cannulae Therapy for Infants and Children with Acute Respiratory Distress Outside of Paediatric Intensive Care

\author{
A review article
}

$$
\begin{aligned}
& \text { استخدام التهوية الغير جراحية والعلاج بالقنيات الأنفية ذات التدفق العالي لعلاج } \\
& \text { المواليد والأطفال المصابين بضائقة تنفسية حادة خارج العناية المركزة للأطفال } \\
& \text { مراجعة أدبية }
\end{aligned}
$$

خلود سعيد المخينية، نجوى مرهون الرحبية

ABSTRACT: Noninvasive ventilation (NIV) and high-flow nasal cannulae therapy (HFNCT) are first-line methods of treatment for children presenting with acute respiratory distress, with paediatric intensive care units (PICUs) providing an ideal environment for subsequent treatment monitoring. However, the availability of step-down units, where NIV and HFNCT can be safely utilised, has reduced the need for such patients to be admitted to PICUs, thereby leading to the better overall utilisation of critical care resources. In addition, NIV and HFNCT can also be used during transport instead of invasive ventilation, thus avoiding the complications associated with the latter approach. This review article examines the safety and applicability of these respiratory support approaches outside of paediatric intensive care as well as various factors associated with treatment success or failure.

Keywords: Critical Care; Children; Pediatric Intensive Care Units; Noninvasive Ventilation; Nasal Cannulae; Transportation of Patients.

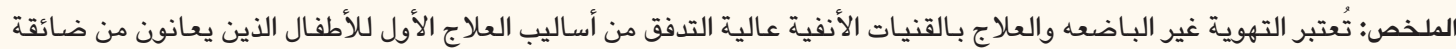

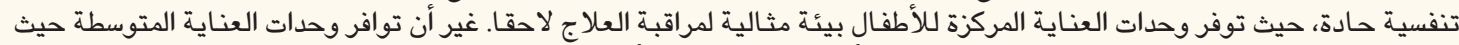

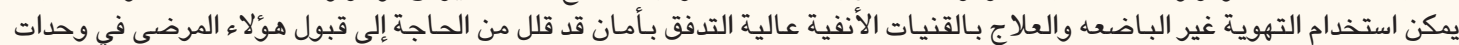

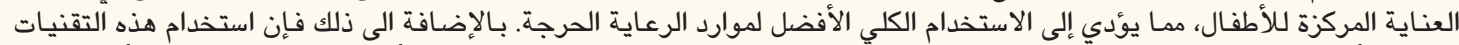

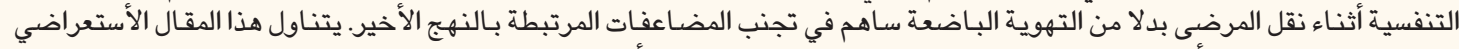

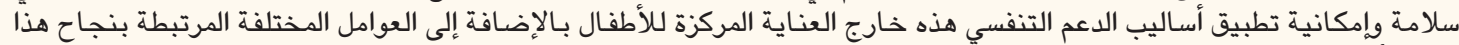

$$
\begin{aligned}
& \text { العلاج أو فشله. } \\
& \text { الكلمات المفتاحية؛ رعاية حرجة؛ أطفال؛ وحدات العناية المركزة للأطفال؛ تهوية غير باضعة. }
\end{aligned}
$$

$\mathrm{N}$ N-INVASIVE VENTILATION (NIV) IS defined as the administration of positive airway pressure through an interface to avoid creating an invasive artificial airway through the trachea. ${ }^{1,2}$ It comprises various techniques, including continuous positive airway pressure (CPAP) and bilevel positive airway pressure. Over the last decade, the use of NIV has significantly increased in the paediatric population. ${ }^{3-5}$ In general, NIV holds several advantages over invasive mechanical ventilation and is associated with improved pulmonary gas exchange. ${ }^{1,2}$ Moreover, the physiological effects of NIV reduce respiratory distress in children presenting with acute respiratory failure. ${ }^{6}$

High-flow nasal cannulae therapy (HFNCT) refers to the delivery of a humidified oxygen and gas mixture at flow rates that equal or exceed the patient's inspiratory flow. ${ }^{7}$ At higher flow rates, this technique can generate positive end-expiratory pressure, although the amount of pressure generated is not predictable. ${ }^{7-9}$ In addition, HFNCT has effects on gas conditioning, thereby reducing energy needs, and is associated with anatomical dead space washout, improving oxygenation and reducing carbon dioxide. ${ }^{7}$ 
Overall, both NIV and HFNCT are superior to invasive ventilation as these methods reduce the risk of infection, need for sedation and treatment costs associated with the latter approach. ${ }^{1,10}$

\section{Safety and Efficacy in Respiratory Diseases}

Variable success rates have been reported in different paediatric diseases following NIV. For instance, favourable results have been observed with primary respiratory diseases including bronchiolitis, asthma and pneumonia. ${ }^{4,5}$ However, NIV has resulted in lower success rates among children diagnosed with acute respiratory distress syndrome (ARDS). ${ }^{5}$ In addition, patients presenting with multi-organ failure have reportedly demonstrated worse outcomes with NIV. ${ }^{5}$

Similarly, HFNCT is widely used to treat infants and children presenting with acute respiratory distress and has been successful for various respiratory diseases including pneumonia, asthma and obstructive sleep apnoea. ${ }^{8,11}$ According to Kawaguchi et al., HFNCT significantly decreased the need for intubation in a cohort of patients with mixed respiratory diseases (38\% versus 63\%; $P<0.001$ ). ${ }^{11}$ Other research has also shown a decrease in intubation rates following HFNCT among infants with severe bronchiolitis (5-9\%)..$^{12-14}$ Nevertheless, a randomised controlled trial (RCT) comparing HFNCT to nasal CPAP demonstrated that the latter method required less escalation of respiratory support and was associated with earlier improvement in respiratory distress among a cohort of young infants with acute viral bronchiolitis. ${ }^{14}$

\section{Application Outside of Paediatric Intensive Care}

Traditionally, NIV and HFNCT were reserved for use in intensive care environments in order to closely monitor the development of any technical issues or complications and assess the need for further treatment. ${ }^{15}$ However, in recent years, both the number of critically ill patients and that of patients requiring readmission to intensive care units (ICUs) has increased. ${ }^{16-19}$ These additional demands on limited intensive care resources have encouraged the application of noninvasive respiratory support methods in non-ICU settings including paediatric wards, emergency rooms (ERs) and during transport. Moreover, the implementation of high-dependency or step-down units with the necessary resources to safely deliver and monitor respiratory support has also assisted in reducing the need for ICU admission. ${ }^{20}$

\section{EMERGENCY ROOMS AND GENERAL WARDS}

Over the past few years, the use of NIV and HFNCT has increased in paediatric wards and ERs. ${ }^{21-23}$ This is because both methods reduce the need for invasive ventilation thereby lowering requirements for escalation to paediatric ICUs (PICUs). ${ }^{2,24}$ In a recent survey conducted across several European countries, 15.5\% and $20 \%$ of participating PICUs reported NIV usage in wards and ERs, respectively. ${ }^{25}$ Moreover, recent reports from France and Finland indicate that HFNCT is increasingly utilised in paediatric wards in hospitals without ICUs with no major adverse events, with HFNCT usage outside of the ICU ranging from 53.3-86.5\%. ${ }^{26,27}$ Table 1 summarises the characteristics and outcomes of various studies evaluating the use of NIV and HFNCT in paediatric ERs and general wards..$^{21-24,28,29}$

Franklin et al. conducted a large multicentre RCT evaluating the use of HFNCT versus low-flow oxygen in 1,472 infants with bronchiolitis managed in a general paediatric ward. ${ }^{24}$ The trial noted that fewer infants in the HFNCT group required escalation to intensive care compared to those treated with low-flow oxygen (12\% versus $23 \%$; $P<0.001$ ). Moreover, $61 \%$ of patients in the low-flow oxygen group required HFNCT as a rescue treatment, subsequently avoiding the need for transfer to the PICU. ${ }^{24}$ Davison et al. described the successful application of HFNCT in an institution without an on-site-PICU; however, the researchers advised strict observation and treatment monitoring and recommended that infants without clinical improvement within 60-90 minutes of treatment be immediately transferred to a PICU. ${ }^{21}$

Various factors have been associated with HFNCT failure in general wards and ERs. In a large retrospective study of 231 paediatric patients treated outside of an ICU, Betters et al. identified underlying cardiac disease and increased fraction of inspired oxygen requirements to be risk factors for HFNCT failure. ${ }^{30}$ However, the researchers also observed that non-responders generally underwent a shorter duration of treatment with HFNCT compared to responders (median duration: 5.5 versus 28 hours). ${ }^{30}$ The use of a treatment protocol to guide the application of HFNCT may help to reduce duration of hospital stay and treatment costs as well as faster weaning. ${ }^{27,31}$

In theER, patients withincreased work ofbreathing at presentation, high initial partial pressure of carbon dioxide measurements and $\mathrm{pH}$ values of $<7.3$ were reportedly more likely to fail HFNCT treatment. ${ }^{28,29}$ Moreover, patients who required intubation were more likely to have features of impending respiratory 
Table 1: Summary of selected studies evaluating the use of noninvasive ventilation and high-flow nasal cannulae therapy in paediatric emergency rooms and general wards ${ }^{21-24,28,29}$

\begin{tabular}{|c|c|c|c|c|c|}
\hline $\begin{array}{l}\text { Author and year } \\
\text { of study }\end{array}$ & Study design & $\begin{array}{l}\text { Mode of } \\
\text { respiratory } \\
\text { support }\end{array}$ & Study setting & Sample & Outcome \\
\hline $\begin{array}{l}\text { Davison et al. } .^{21} \\
(2017)\end{array}$ & $\begin{array}{l}\text { Retrospective } \\
\text { study }\end{array}$ & HFNCT & $\begin{array}{l}\text { Non-tertiary } \\
\text { ER and } \\
\text { paediatric } \\
\text { wards }\end{array}$ & $\begin{array}{l}61 \text { infants and } \\
\text { children aged } \\
1-23 \text { months } \\
\text { with suspected } \\
\text { bronchiolitis }\end{array}$ & $\begin{array}{l}\text { - Two-thirds of the patients } \\
\text { underwent HFNCT in } \\
\text { paediatric wards with no } \\
\text { adverse effects. } \\
\text { - Only } 13 \% \text { of patients required } \\
\text { transfer to an off-site PICU. }\end{array}$ \\
\hline $\begin{array}{l}\text { Ballestero et } a l .{ }^{22} \\
(2018)\end{array}$ & $\begin{array}{l}\text { Prospective } \\
\text { randomised } \\
\text { pilot study }\end{array}$ & $\begin{array}{l}\text { Low-flow } \\
\text { oxygen } \\
\text { versus } \\
\text { HFNCT }\end{array}$ & $\begin{array}{c}\text { Tertiary } \\
\text { paediatric ER }\end{array}$ & $\begin{array}{l}62 \text { children aged } \\
1-14 \text { years with } \\
\text { refractory asthma } \\
\text { and respiratory } \\
\text { failure }\end{array}$ & $\begin{array}{l}\text { - HFNCT was superior to } \\
\text { low-flow oxygen in improving } \\
\text { respiratory distress within two } \\
\text { hours of treatment. }\end{array}$ \\
\hline $\begin{array}{l}\text { Vitaliti et al. }{ }^{23} \\
(2013)\end{array}$ & $\begin{array}{l}\text { Retrospective } \\
\text { study }\end{array}$ & NIV & Paediatric ER & $\begin{array}{l}\text { Children } \\
\text { presenting with } \\
\text { respiratory } \\
\text { distress }\end{array}$ & $\begin{array}{l}\text { - NIV led to improvements } \\
\text { in WOB and pulmonary gas } \\
\text { exchange. } \\
\text { - In addition, NIV reduced the } \\
\text { need for PICU transfer. }\end{array}$ \\
\hline Long et al. ${ }^{29}$ (2016) & $\begin{array}{l}\text { Prospective } \\
\text { observational } \\
\text { study }\end{array}$ & HFNCT & ER & 71 patients & $\begin{array}{l}\text { The majority of patients } \\
\text { improved following HFNCT, } \\
\text { with only } 39 \% \text { requiring } \\
\text { escalation of respiratory } \\
\text { support. }\end{array}$ \\
\hline
\end{tabular}

$R C T=$ randomised controlled trial; HFNCT = high-flow nasal cannulae therapy; ER = emergency room; PICU = paediatric intensive care unit; $N I V=$ noninvasive ventilation; $W O B=$ work of breathing.

failure at their initial assessment. ${ }^{28}$ In contrast, certain respiratory conditions such as bronchiolitis have been associated with HFNCT success. ${ }^{28,30}$

\section{DURING TRANSPORT}

The popularity of noninvasive respiratory approaches during transport has also increased in recent years. The European survey reported that $36.4 \%$ of participating PICUs used NIV during paediatric transport. ${ }^{25} \mathrm{~A}$ summary of previous research evaluating the use of NIV and HFNCT during paediatric transport is presented in Table 2. ${ }^{32-38}$ Unfortunately, all of the studies evaluating NIV and HFNCT outcomes during transport were observational in nature. Therefore, there is a need for RCTs comparing outcomes with HFNCT to those of CPAP and other modes of NIV during paediatric and neonatal transport.
Schlapbach et al. compared outcomes following HFNCT during transport with that of a historical cohort transferred prior to the introduction of HFNCT. ${ }^{32}$ Overall, $49 \%$ of patients in the pre-HFNCT era were intubated during transport compared to $35 \%$ in the period following HFNCT introduction $(P<0.001)$. Similarly, NIV utilisation also decreased following the introduction of HFNCT (7\% versus $2 \%$ ). ${ }^{32}$ In total, 33\% of the patients received HFNCT during transport in the latter era, with no significant adverse events noted, including the need for intubation or cardiopulmonary resuscitation. ${ }^{32}$ Abraham et al. also confirmed the safety of HFNCT usage during transfer in a retrospective study of 114 infants, although $23 \%$ subsequently required escalation of respiratory support following transfer. ${ }^{33}$ 
Table 2: Summary of selected research evaluating the use of noninvasive ventilation and high-flow nasal cannulae therapy during paediatric transport ${ }^{32-38}$

\begin{tabular}{|c|c|c|c|c|}
\hline $\begin{array}{l}\text { Author and year } \\
\text { of study }\end{array}$ & Study design & $\begin{array}{c}\text { Mode of } \\
\text { respiratory support }\end{array}$ & Sample & Outcome \\
\hline $\begin{array}{l}\text { Schlapbach et al. } .^{32} \\
(2014)\end{array}$ & $\begin{array}{l}\text { Retrospective } \\
\text { study }\end{array}$ & $\begin{array}{l}\text { Invasive ventilation, } \\
\text { NIV or HFNCT }\end{array}$ & 793 infants aged $\leq 2$ years & $\begin{array}{l}\text { - The frequency of both invasive } \\
\text { ventilation ( } 49 \% \text { versus } 35 \%) \text { and } \\
\text { NIV ( } 7 \% \text { versus } 2 \%) \text { decreased } \\
\text { following the introduction of } \\
\text { HFNCT. } \\
\text { - Overall, } 33 \% \text { of infants underwent } \\
\text { HFNCT during transport. } \\
\text { - No adverse effects were noted } \\
\text { among those who underwent } \\
\text { HFNCT during transport. }\end{array}$ \\
\hline $\begin{array}{l}\text { Abraham et al. }{ }^{33} \\
(2019)\end{array}$ & $\begin{array}{l}\text { Retrospective } \\
\text { study }\end{array}$ & HFNCT & $\begin{array}{l}\text { 114 infants, of which } 50 \% \\
\text { had bronchiolitis }\end{array}$ & $\begin{array}{l}\text { - No adverse events were observed } \\
\text { during transport. } \\
\text { - The method of respiratory support } \\
\text { was changed to NIV (CPAP) before } \\
\text { transport in } 3 \% \text { of patients. } \\
\text { - Post-transport, } 23 \% \text { of patients } \\
\text { required escalation of respiratory } \\
\text { support. }\end{array}$ \\
\hline $\begin{array}{l}\text { Fleming et al. }{ }^{34} \\
(2012)\end{array}$ & $\begin{array}{l}\text { Retrospective } \\
\text { study }\end{array}$ & NIV (CPAP) & $\begin{array}{l}54 \text { infants with suspected } \\
\text { bronchiolitis }\end{array}$ & $\begin{array}{l}\text { - No adverse events were noted } \\
\text { during transport. } \\
\text { - However, } 10 \% \text { required intubation } \\
\text { within } 24 \text { hours of transport. }\end{array}$ \\
\hline $\begin{array}{l}\text { Resnick and } \\
\text { Sokol }^{35}(2010)\end{array}$ & $\begin{array}{l}\text { Retrospective } \\
\text { study }\end{array}$ & NIV (CPAP) & $\begin{array}{l}369 \text { neonates aged } \geq 32 \\
\text { gestational weeks with } \\
\text { acute respiratory distress }\end{array}$ & $\begin{array}{l}\text { - During the two-year study period, } \\
\text { CPAP use increased from } 33 \% \text { to } \\
59 \% \text {. } \\
\text { - Overall, } 13 \% \text { of the neonates } \\
\text { required intubation within } 24 \text { hours } \\
\text { of transport, likely due to higher } \\
\text { initial oxygen requirements. } \\
\text { - There was no significant morbidity } \\
\text { or mortality. }\end{array}$ \\
\hline $\begin{array}{l}\text { Baird et al. }{ }^{36} \\
(2009)\end{array}$ & $\begin{array}{l}\text { Retrospective } \\
\text { study }\end{array}$ & $\begin{array}{l}\text { NIV (CPAP and } \\
\text { BPAP) }\end{array}$ & $\begin{array}{c}25 \text { children and } \\
\text { teenagers aged } \leq 18 \text { years }\end{array}$ & $\begin{array}{l}\text { - Overall, } 64 \% \text { and } 36 \% \text { of patients } \\
\text { were transported on CPAP and } \\
\text { BPAP, respectively. } \\
\text { - No adverse events were observed } \\
\text { during transport. } \\
\text { - However, } 35 \% \text { of patients required } \\
\text { intubation within } 84 \text { hours of } \\
\text { transport. }\end{array}$ \\
\hline $\begin{array}{l}\text { Millán et al. }{ }^{37} \\
(2017)\end{array}$ & $\begin{array}{l}\text { Prospective } \\
\text { observational } \\
\text { study }\end{array}$ & $\begin{array}{l}\text { Invasive ventilation, } \\
\text { NIV (CPAP) or OCN }\end{array}$ & $\begin{array}{c}288 \text { children aged } \leq 17 \\
\text { months with acute } \\
\text { respiratory failure, } \\
\text { of which } 58 \% \text { had } \\
\text { bronchiolitis }\end{array}$ & $\begin{array}{l}\text { - Overall, } 19 \%, 37 \% \text { and } 44 \% \text { of } \\
\text { patients were transported on } \\
\text { invasive ventilation, CPAP and } \\
\text { OCN, respectively. } \\
\text { - Minor adverse events (i.e. } \\
\text { intolerance to the interface) were } \\
\text { observed in } 3 \% \text { of patients. } \\
\text { - One patient required intubation } \\
\text { during transport. }\end{array}$ \\
\hline $\begin{array}{l}\text { Cheema et al. } .^{38} \\
(2018)\end{array}$ & $\begin{array}{l}\text { Systematic } \\
\text { review }\end{array}$ & $\begin{array}{c}\text { NIV (CPAP) and } \\
\text { HFNCT }\end{array}$ & $\begin{array}{l}858 \text { neonates and } \\
\text { children }\end{array}$ & $\begin{array}{l}\text { - The rate of minor adverse events } \\
\text { was } 1-4 \% \text {. } \\
\text { - Only } 0.4 \% \text { of patients required } \\
\text { intubation or escalation of support } \\
\text { during transfer. } \\
\text { - Overall, } 10 \% \text { needed intubation } \\
\text { within } 24 \text { hours of transfer. } \\
\text { - The odds of intubation within } \\
24 \text { hours were higher for patients } \\
\text { on CPAP compared to those on } \\
\text { HFNCT. }\end{array}$ \\
\hline
\end{tabular}

NIV = noninvasive ventilation HFNCT = high-flow nasal cannulae therapy CPAP = continuous positive airway pressure; $B P A P=$ bilevel positive airway pressure; $\mathrm{OCN}=$ oxygen cannula/nebulisation.

Boyle et al. concluded that HFNCT was a safe option for transporting neonates, provided that the neonate was stable for 24 hours pre-transfer and certain pre-requisites were met concerning age, weight and flow at the time of transfer. ${ }^{39}$ Moreover, the researchers noted that HFNCT usage was associated 
with increased comfort for patients, as well as a reduction in the need to change the mode of respiratory support for the purposes of patient stabilisation before transfer. ${ }^{39}$ Similarly, a large prospective study of 288 children with acute respiratory failure found that stabilisation occurred more rapidly with NIV compared to invasive ventilation (median time: 48 versus 83 minutes; $P<0.001){ }^{36}$

Other research has also shown that NIV and HFNCT usage during transport is safe and feasible and reduces the need for invasive ventilation. ${ }^{34,35}$ Cheema et $a l$. noted that the rate of adverse events was low (1-4\%) in a systematic review of eight observational studies evaluating NIV and HFNCT usage during paediatric transport. ${ }^{38}$ Observed side-effects included apnoea and the need for cardiopulmonary resuscitation or bag mask ventilation. However, only $0.4 \%$ required intubation or escalation of respiratory support during transport, although 10\% required intubation within 24 hours of transfer. ${ }^{38}$

Regardless of mode of respiratory support, specialised retrieval teams are essential to the safe transfer of patients. In an observational study of paediatric transfers over a six-month period, Barry and Ralston reported that patient retrieval by non-specialised teams was linked with complications during transfer. ${ }^{40}$ In addition, researchers have noted certain clinical contraindications for transporting children on NIV. ${ }^{36,37}$ An early study assessing the safety of NIV during transport reported no adverse events; however, this approach was not considered for children diagnosed with shock, cardiopulmonary arrest or trauma to the head and neck. ${ }^{36}$ According to Millán et al., this respiratory support approach should be considered only in the presence of a well-trained transport team. ${ }^{37}$ The authors also recommended the application of strict inclusion and exclusion criteria when selecting patients. For example, the researchers considered NIV usage during transport to be unsuitable for children with a diagnosis of ARDS and those requiring high NIV settings or demonstrating a lack of clinical response to NIV. ${ }^{37}$

\section{Conclusion}

According to the available literature, the application of HFNCT or NIV respiratory approaches in nonintensive care environments seems to be safe and feasible, provided that continuous monitoring and specialised staff are available. In addition, institutional protocols for the early evaluation of children with acute respiratory distress may be useful to determine the necessity for further escalation of therapy or PICU transfer.

\section{References}

1. Antonelli M, Conti G, Rocco M, Bufi M, De Blasi RA, Vivino G, et al. A comparison of noninvasive positive-pressure ventilation and conventional mechanical ventilation in patients with acute respiratory failure. N Engl J Med 1998; 339:429-35. https://doi. org/10.1056/NEJM199808133390703.

2. Yañez LJ, Yunge M, Emilfork M, Lapadula M, Alcántara A, Fernández $\mathrm{C}$, et al. A prospective, randomized, controlled trial of noninvasive ventilation in pediatric acute respiratory failure. Pediatr Crit Care Med 2008; 9:484-9. https://doi.org/10.1097/ PCC.0b013e318184989f.

3. Ganu SS, Gautam A, Wilkins B, Egan J. Increase in use of non-invasive ventilation for infants with severe bronchiolitis is associated with decline in intubation rates over a decade. Intensive Care Med 2012; 38:1177-83. https://doi.org/10.1007/ s00134-012-2566-4.

4. Wolfler A, Calderini E, Iannella E, Conti G, Biban P, Dolcini A, et al. Evolution of noninvasive mechanical ventilation use: A cohort study among Italian PICUs. Pediatr Crit Care Med 2015; 16:418-27. https://doi.org/10.1097/PCC.0000000000000387.

5. Essouri S, Chevret L, Durand P, Haas V, Fauroux B, Devictor D. Noninvasive positive pressure ventilation: Five years of experience in a pediatric intensive care unit. Pediatr Crit Care Med 2006; 7:329-34. https://doi.org/10.1097/01.PCC.00002250 89.21176.0B

6. Essouri S, Durand P, Chevret L, Haas V, Perot C, Clement A, et al. Physiological effects of noninvasive positive ventilation during acute moderate hypercapnic respiratory insufficiency in children. Intensive Care Med 2008; 34:2248-55. https://doi. org/10.1007/s00134-008-1202-9.

7. Milési C, Boubal M, Jacquot A, Baleine J, Durand S, Odena MP, et al. High-flow nasal cannula: Recommendations for daily practice in pediatrics. Ann Intensive Care 2014; 4:29. https://doi.org/10.11 86/s13613-014-0029-5

8. Mikalsen IB, Davis P, Øymar K. High flow nasal cannula in children: A literature review. Scand J Trauma Resusc Emerg Med 2016; 24:93. https://doi.org/10.1186/s13049-016-0278-4.

9. Lee JH, Rehder KJ, Williford L, Cheifetz IM, Turner DA. Use of high flow nasal cannula in critically ill infants, children, and adults: A critical review of the literature. Intensive Care Med 2013; 39:247-57. https://doi.org/10.1007/s00134-012-2743-5.

10. Essouri S, Laurent M, Chevret L, Durand P, Ecochard E, Gajdos V, et al. Improved clinical and economic outcomes in severe bronchiolitis with pre-emptive nCPAP ventilator strategy. Intensive Care Med 2014; 40:84-91. https://doi.org/10.1007/s00134-013-3129-z.

11. Kawaguchi A, Yasui Y, deCaen A, Garros D. The clinical impact of heated humidified high-flow nasal cannula on pediatric respiratory distress. Pediatr Crit Care Med 2017; 18:112-19. https://doi.org/10.1097/PCC.0000000000000985.

12. McKiernan C, Chua LC, Visintainer PF, Allen H. High flow nasal cannulae therapy in infants with bronchiolitis. J Pediatr 2010; 156:634-8. https://doi.org/10.1016/j.jpeds.2009.10.039.

13. Schibler A, Pham TM, Dunster KR, Foster K, Barlow A, Gibbons K, et al. Reduced intubation rates for infants after introduction of high-flow nasal prong oxygen delivery. Intensive Care Med 2011; 37:847-52. https://doi.org/10.1007/s00134-011-2177-5.

14. Milési C, Essouri S, Pouyau R, Liet JM, Afanetti M, Portefaix A, et al. High flow nasal cannula (HFNC) versus nasal continuous positive airway pressure (nCPAP) for the initial respiratory management of acute viral bronchiolitis in young infants: A multicenter randomized controlled trial (TRAMONTANE study). Intensive Care Med 2017; 43:209-16. https://doi.org/10.1007/s00 134-016-4617-8.

15. Cabrini L, Moizo E, Nicelli E, Licini G, Turi S, Landoni G, et al. Noninvasive ventilation outside the intensive care unit from the patient point of view: A pilot study. Respir Care 2012; 57:704-9. https://doi.org/10.4187/respcare.01474. 
16. Randolph AG, Gonzales CA, Cortellini L, Yeh TS. Growth of pediatric intensive care units in the United States from 1995 to 2001. J Pediatr 2004; 144:792-8. https://doi.org/10.1016/j. jpeds.2004.03.019.

17. Yoon JS, Jhang WK, Choi YH, Lee B, Kim YH, Cho HJ, et al. Current status of pediatric critical care in Korea: Results of 2015 national survey. J Korean Med Sci 2018; 33:e308. https://doi.org/10.3346/jkms.2018.33.e308.

18. Khanal A, Sharma A, Basnet S. Current state of pediatric intensive care and high dependency care in Nepal. Pediatr Crit Care Med 2016; 17:1032-40. https://doi.org/10.1097/ PCC.0000000000000938.

19. Choong K, Fraser D, Al-Harbi S, Borham A, Cameron J, Cameron S, et al. Functional recovery in critically ill children, the "WeeCover" multicenter study. Pediatr Crit Care Med 2018; 19:145-54. https://doi.org/10.1097/PCC.0000000000001421.

20. Scala R. Respiratory high-dependency care units for the burden of acute respiratory failure. Eur J Intern Med 2012; 23:302-8. https://doi.org/10.1016/j.ejim.2011.11.002.

21. Davison M, Watson M, Wockner L, Kinnear F. Paediatric highflow nasal cannula therapy in children with bronchiolitis: A retrospective safety and efficacy study in a nontertiary environment. Emerg Med Australas 2017; 29:198-203. https://doi.org/10.11 11/1742-6723.12741.

22. Ballestero Y, De Pedro J, Portillo N, Martinez-Mugica O, AranaArri E, Benito J. Pilot clinical trial of high-flow oxygen therapy in children with asthma in the emergency service. J Pediatr 2018; 194:204-10.e3. https://doi.org/10.1016/j.jpeds.2017.10.075.

23. Vitaliti G, Wenzel A, Bellia F, Pavone P, Falsaperla R. Noninvasive ventilation in pediatric emergency care: A literature review and description of our experience. Expert Rev Respir Med 2013; 7:545-52. https://doi.org/10.1586/17476348.2013.816570.

24. Franklin D, Babl FE, Schlapbach LJ, Oakley E, Craig S, Neutze J, et al. A randomized trial of high-flow oxygen therapy in infants with bronchiolitis. N Engl J Med 2018; 378:1121-31. https://doi.org/10.1056/NEJMoa1714855.

25. Mayordomo-Colunga J, Pons-Òdena M, Medina A, Rey C, Milesi C, Kallio M, et al. Non-invasive ventilation practices in children across Europe. Pediatr Pulmonol 2018; 53:1107-14. https://doi.org/10.1002/ppul.23988.

26. Panciatici M, Fabre C, Tardieu S, Sauvaget E, Dequin M, Stremier-Le Bel N, et al. Use of high-flow nasal cannula in infants with viral bronchiolitis outside pediatric intensive care units. Eur J Pediatr 2019; 178:1479-84. https://doi.org/10.1007/ s00431-019-03434-4.

27. Sokuri P, Heikkilä P, Korppi M. National high-flow nasal cannula and bronchiolitis survey highlights need for further research and evidence-based guidelines. Acta Pediatr 2017; 106:1998-2003. https://doi.org/10.1111/apa.13964.

28. Kelly GS, Simon HK, Sturm JJ. High-flow nasal cannula use in children with respiratory distress in the emergency department: Predicting the need for subsequent intubation. Pediatr Emerg Care 2013; 29:888-92. https://doi.org/10.1097/ PEC.0b013e31829e7f2f.
29. Long E, Babl FE, Duke T. Is there a role for humidified heated highflow nasal cannula therapy in paediatric emergency departments? Emerg Med J 2016; 33:386-9. https://doi.org/10.1136/emerm ed-2015-204914

30. Betters KA, Gillespie SE, Miller J, Kotzbauer D, Hebbar KB. High flow nasal cannula use outside of the ICU: Factors associated with failure. Pediatr Pulmonol 2017; 52:806-12. https://doi.org/10.1002/ppul.23626.

31. Riese J, Fierce J, Riese A, Alverson BK. Effect of a hospital-wide high-flow nasal cannula protocol on clinical outcomes and resource utilization of bronchiolitis patients admitted to the PICU. Hosp Pediatr 2015; 5:613-18. https://doi.org/10.1542/ hpeds.2014-0220.

32. Schlapbach LJ, Schaefer J, Brady AM, Mayfield S, Schibler A. High-flow nasal cannula (HFNC) support in interhospital transport of critically ill children. Intensive Care Med 2014; 40:592-9. https://doi.org/10.1007/s00134-014-3226-7.

33. Abraham V, Manley BJ, Owen LS, Stewart MJ, Davis PG, Roberts CT. Nasal high-flow during neonatal and infant transport in Victoria, Australia. Acta Paediatr 2019; 108:768-9. https://doi.org/10.1111/apa.14650.

34. Fleming PF, Richards S, Waterman K, Davis PG, Kamlin CO, Soko J, et al. Use of continuous positive airway pressure during stabilisation and retrieval of infants with suspected bronchiolitis. J Paediatr Child Health 2012; 48:1071-5. https://doi.org/10.11 11/j.1440-1754.2012.02468.x.

35. Resnick S, Sokol J. Impact of introducing binasal continuous positive airway pressure for acute respiratory distress in newborns during retrieval: Experience from Western Australia. J Paediatr Child Health 2010; 46:754-9. https://doi.org/10.1111/j.14401754.2010.01834.x

36. Baird JS, Spiegelman JB, Prianti R, Frudak S, Schleien CL. Noninvasive ventilation during pediatric interhospital ground transport. Prehosp Emerg Care 2009; 13:198-202. https://doi. org/10.1080/10903120802706112.

37. Millán N, Alejandre C, Martinez-Planas A, Cartig J, Esteban E, Pons-Òdena M. Noninvasive respiratory support during pediatric ground transport: Implementation of a safe and feasible procedure. Respir Care 2017; 62:558-65. https://doi.org/10.4187/resp care.05253.

38. Cheema B, Welzel T, Rossouw B. Noninvasive ventilation during pediatric and neonatal critical care transport: A systematic review. Pediatr Crit Care Med 2018; 20:9-18. https://doi.org/10.10 97/PCC.0000000000001781.

39. Boyle MA, Dhar A, Broster S. Introducing high-flow nasal cannula to the neonatal transport environment. Acta Paediatr 2017; 106:1363. https://doi.org/10.1111/apa.13910.

40. Barry PW, Ralston C. Adverse events occurring during interhospital transfer of the critically ill. Arch Dis Child 1994; 71:8-11. https://doi.org/10.1136/adc.71.1.8. 